\title{
Yield performance of introduced cassava clones in an Ultisol in Puerto Rico ${ }^{1,2}$
}

\author{
Ricardo Goenaga, ${ }^{3}$ Edmundo Rivera-Amador ${ }^{4}$ \\ and Ulises Chardón ${ }^{5}$
}

J. Agric. Univ. P. R. 86(1-2):27-33 (2002)

\begin{abstract}
In 2000 , cassava production in Puerto Rico was almost $750,000 \mathrm{~kg}$ with an annual farm value of $\$ 386,000$. During the same year more than $6,800,000$ $\mathrm{kg}$ of cassava tubers were imported. Studies with new introductions of cassava clones are necessary to increase production, reduce costs and meet local demand. Seven cassava introductions and one local cultivar were evaluated in 1997 and 1998 at Corozal for yield and hydrogen cyanide (HCN) concentration. Clones CM 3380, CM 3311, SG 804 and SM 494 produced the highest number of marketable roots. Clones CM 3311, CM 3380 and SG 804 produced the highest root marketable weight in 1997, averaging $37,905 \mathrm{~kg} /$ ha. In 1998, clones CM 3311 and CM 3380 were the best yielders, averaging $28,713 \mathrm{~kg} / \mathrm{ha}$ of marketable roots. In both years clone SG 804 had a significantly higher concentration of $\mathrm{HCN}$, which averaged $121 \mathrm{mg} / \mathrm{kg}$, whereas the rest of the clones had values of $\mathrm{HCN}$ below $63 \mathrm{mg} / \mathrm{kg}$.
\end{abstract}

Key words: cassava, yield, $\mathrm{HCN}$ concentration

\section{RESUMEN}

Rendimiento de clones introducidos de yuca en un Ultisol en Puerto Rico

En el año 2000 la producción de yuca en Puerto Rico fue de $750,000 \mathrm{~kg}$ con un valor en la finca de $\$ 386,000$. El mismo año se importaron $6,800,000$ $\mathrm{kg}$ de yuca a la isla. Es necesaio que se realicen estudios encaminados a evaluar nuevas introducciones de yuca para aumentar la producción y satisfacer la demanda local. Siete introducciones de yuca y un cultivar local fueron evaluados para rendimiento y concentración de cianuro (HCN) en Corozal en 1997 y 1998. Los clones CM 3380, CM 3311, SG 804 y SM 494 produjeron el mayor número de raíces mercadeables. En 1997 los clones CM 3311, CM 3380 y SG 804 produjeron las raíces mercadeables con mayor peso, promediando $37,905 \mathrm{~kg} / \mathrm{ha}$. En 1998, los clones CM 3311 y CM 3380 obtuvieron los mayores rendimientos, promediando $28,713 \mathrm{~kg} /$ ha de raíces mercadeables. En ambos años el clon SG 804 obtuvo una concentración de

${ }^{1}$ Manuscript submitted to Editorial Board 6 February 2002.

2This paper covers work carried out cooperatively between the Agricultural Research Station-USDA and the Agricultural Experiment Station, University of Puerto Rico (AES-UPR), Río Piedras, PR. The authors acknowledge the excellent field assistance of Nicolás Díaz and Tomás Miranda during the course of this investigation.

${ }^{3}$ Research Plant Physiologist (mayrg@ars-grin.gov), USDA, ARS, Tropical Agriculture Research Station, 2200 Pedro Albizu Campos Ave., Suite 201, Mayagüez, PR 00680-5470.

${ }^{4}$ Agronomist, USDA, ARS, Tropical Agriculture Research Station, Mayagüez, PR.

${ }^{5}$ Chemist, USDA, ARS, Tropical Agriculture Research Station, Mayagüez, PR. 
HCN significativamente más alta $(121 \mathrm{mg} / \mathrm{kg})$ mientras que en los demás clones la concentración de HCN fue menor de $63 \mathrm{mg} / \mathrm{kg}$.

\section{INTRODUCTION}

Cassava is one of the most important energy sources in the diet of large segments of the population in the tropics. National worldwide average yields vary widely, from $1,780 \mathrm{~kg} / \mathrm{ha}$ in Sudan to more than $27,300 \mathrm{~kg} /$ ha in Barbados (FAO, 2000). Much cassava is grown without irrigation in tropical areas with a pronounced dry period, and often in soils of low fertility (Howeler, 1996). In 1999-2000, cassava production in Puerto Rico was almost $750,000 \mathrm{~kg}$ with an annual farm value of $\$ 386,000$ (Departamento de Agricultura, 2000) whereas average yield was $2,454 \mathrm{~kg} / \mathrm{ha}$ (FAO, 2000). During the same year more than $6,800,000 \mathrm{~kg}$ of cassava tubers was imported (Puerto Rico Planning Board, 2000). Therefore, an incentive exists to increase production to meet local demand and perhaps export to other markets in the Caribbean Basin.

In 1980, Ramírez et al. (1983) tested 10 promising cassava cultivars which ranged in yield from $8,435 \mathrm{~kg} / \mathrm{ha}$ to $29,442 \mathrm{~kg} / \mathrm{ha}$. From 1980 to 1983, Badillo-Feliciano (1984) evaluated 12 local and introduced clones of cassava in an Oxisol. The highest yield $(39,921 \mathrm{~kg} / \mathrm{ha})$ was attained by cultivar IAC-Mantequeira (PI 12902). To our knowledge, since then studies to evaluate yield potential of new cassava introductions have not been conducted in Puerto Rico or elsewhere in the Caribbean. The objective of the study was to evaluate seven cassava introductions and one local cultivar in Puerto Rico for yield and HCN content.

\section{MATERIALS AND METHODS}

Field experiments were established 13 March 1997 and 25 March 1998 at the Corozal Agricultural Experiment Substation of the University of Puerto Rico (latitude $18^{\circ} 20^{\prime} \mathrm{N}$, longitude $66^{\circ} 31^{\prime} \mathrm{W}$, altitude 185 $\mathrm{m}$ ) in the highland agricultural zone of Puerto Rico. The Corozal soil is a well-drained Ultisol (clayey, mixed, isohyperthermic Aquic Haplohumults) with a $\mathrm{pH}$ of $5.1,15 \%$ slope, bulk density of $1.4 \mathrm{~g} / \mathrm{cm}^{3}$, and $2.28 \%$ organic carbon in the first $14 \mathrm{~cm}$ of soil. The 27 -year mean annual rainfall is $1,863 \mathrm{~mm}$ and Class A pan evaporation is $1,391 \mathrm{~mm}$. Table 1 shows total monthly rainfall, evaporation and mean maximum and minimum temperatures during the experimental period.

The cassava clones tested in this study (CM 3064-4, CM 3311-3, CM 3380-7, CM 4484-2, SG 804-5, SM 494-2, CM 523-7) are introduced selections developed by the 'Centro Internacional de Agricultura Tropical' (CIAT) at Cali, Colombia. The local cultivar Serrallés was used as a control. 
TABLE 1.-Average maximum and minimum air temperature, total rainfall, and class $A$ pan evaporation during the experimental period at Corozal, Puerto Rico.

\begin{tabular}{|c|c|c|c|c|}
\hline \multirow[b]{2}{*}{ Month } & \multicolumn{2}{|c|}{ Temperatures $\left({ }^{\circ} \mathrm{C}\right)$} & \multirow{2}{*}{$\begin{array}{c}\text { Rainfall } \\
(\mathrm{mm})\end{array}$} & \multirow{2}{*}{$\begin{array}{c}\text { Pan evaporation } \\
\text { (mm) }\end{array}$} \\
\hline & Maximum & Minimum & & \\
\hline \multicolumn{5}{|l|}{$1997-1998$} \\
\hline March & 29.5 & 17.1 & 7.9 & 81.5 \\
\hline April & 30.6 & 17.6 & 26.7 & 141.0 \\
\hline May & 32.9 & 19.4 & 127.5 & 177.3 \\
\hline June & 33.1 & 21.0 & 26.4 & 173.2 \\
\hline July & 32.7 & 21.3 & 114.0 & 158.0 \\
\hline August & 32.7 & 21.5 & 119.9 & 151.4 \\
\hline September & 32.3 & 21.4 & 191.3 & 128.3 \\
\hline October & 31.5 & 20.9 & 85.1 & 111.2 \\
\hline November & 29.2 & 18.9 & 69.6 & 83.6 \\
\hline December & 32.0 & 19.0 & 2.5 & 123.4 \\
\hline January & 30.1 & 18.5 & 171.4 & 104.1 \\
\hline February & 29.7 & 18.0 & 177.3 & 104.6 \\
\hline March $^{1}$ & 30.3 & 17.0 & 84.1 & 130.0 \\
\hline Average & 31.3 & 19.3 & 92.6 & 128.3 \\
\hline \multicolumn{5}{|l|}{ 1998-1999 } \\
\hline March" $^{2}$ & 30.3 & 18.8 & 55.6 & 26.2 \\
\hline April & 29.9 & 19.3 & 150.6 & 112.3 \\
\hline May & 31.6 & 19.9 & 158,0 & 117.3 \\
\hline June & 32.4 & 21.1 & 143.5 & 136.1 \\
\hline July & 32.5 & 21.4 & 98.0 & 150.9 \\
\hline August & 32.6 & 21.6 & 162.0 & 138.7 \\
\hline September & 32.5 & 21.3 & 258.6 & 126.2 \\
\hline October & 32.0 & 20.9 & 321.8 & 120.6 \\
\hline November & 30.0 & 19.9 & 262.4 & 100.6 \\
\hline December & 27.8 & 19.5 & 436.9 & 89.9 \\
\hline January & 28.2 & 17.9 & 82.5 & 98.3 \\
\hline Average & 30.9 & 20.1 & 193.6 & 110.6 \\
\hline
\end{tabular}

${ }^{1}$ Average of first four days of the month.

${ }^{2}$ Average of last 27 days of the month.

In both experiments, the planting material consisted of mature stem cuttings containing four to five nodes planted vertically in raised beds. The experimental design consisted of a randomized complete block design with five replications. Each replication contained eight plots representing different clones. Each plot consisted of four rows $1.2 \mathrm{~m}$ apart with plants spaced $0.90 \mathrm{~m}$ apart within the row for a total of 20 plants per treatment per replicate. Yield data were recorded only from 
the six inner plants from each plot. The crop was fertilized at a rate of $1,000 \mathrm{~kg} / \mathrm{ha}$ of $15-2.2-12.4-3 \%$ (N-P-K-Mg), which was equally divided and applied at one and four months after planting. Supplemental overhead irrigation was applied as needed. Weed and insect control followed the recommendations of the University of Puerto Rico Agricultural Experiment Station (1997). Harvesting was 4 March 1998 and 20 January 1999, respectively, for each experiment. Damaged or deformed roots were classified as non-marketable. At each harvest, representative marketable roots from each variety were washed free of soil, and potential hydrogen cyanide (PHCN) was determined by the alkaline picrate method (CIAT, 1985).

Analysis of variance was made using the ANOVA procedure of the SAS program package (SAS Institute, 1990). Means among clones for all measurements were separated by Fisher's protected Least Significant Difference (LSD) at the 0.05 probability level.

\section{RESULTS AND DISCUSSION}

Year had a significant $(\mathrm{P} \leq 0.01)$ effect on most of the variables that were studied. This was probably attributable to differences in rainfall. Average monthly rainfall during the 1998-99 experiment was $110 \%$ higher than in 1997-98 (Table 1) and 25\% higher than the 27-yr average for the site. Over 60\% of the total rain received in 1998-1999 fell during the months of September to December. On 21 September 1998, hurricane Georges hit the island of Puerto Rico bringing heavy rains and sustained winds of $177 \mathrm{~km} / \mathrm{h}$. In view of these differences in climatic conditions, experimental data are presented separately for each year.

Clone CM 3380 produced the highest number of marketable roots in both years. However, this trait was not significantly different from that obtained in clones SG 804, CM 3311, SM 494 and CM 523 in 1997 and from clone CM 3311 in 1998 (Table 2). It is noteworthy that in 1998 the number of marketable roots declined between $14 \%$ and $55 \%$ in all clones except CM 3380. The number of marketable roots in the latter declined by only $7 \%$ (Table 2 ). A smaller number of marketable roots in 1998 was the result of root damage from excess soil water brought about by heavy rains that year.

Clones CM 3064 and SM 494 produced the highest number of nonmarketable roots in 1997, averaging 66,861 roots per hectare. In 1998, clone CM 3064 produced a significantly higher number of non-marketable roots (Table 2).

As compared to 1997, the average total number of roots was $13 \%$ lower in 1998 (Table 2). However, it is noteworthy that even though some clones had a decline in the total number of roots of over $20 \%$ in 
TABLE 2.-Number (no./ha) and weight ( $\mathrm{kg} / \mathrm{ha}$ ) of marketable and non-marketable roots, and root $\mathrm{HCN}$ concentration $(\mathrm{mg} / \mathrm{kg}$ ) of eight cassava clones grown at Corozal, Puerto Rico.

\begin{tabular}{|c|c|c|c|c|c|c|c|}
\hline \multirow[b]{2}{*}{ Clone } & \multicolumn{3}{|c|}{ Number of roots } & \multicolumn{3}{|c|}{ Weight of roots } & \multirow[b]{2}{*}{$\mathrm{HCN}$} \\
\hline & $\begin{array}{l}\text { Market- } \\
\text { able }\end{array}$ & $\begin{array}{l}\text { Non-mar- } \\
\text { ketable }\end{array}$ & Total & $\begin{array}{l}\text { Market- } \\
\text { able }\end{array}$ & $\begin{array}{l}\text { Non-mar- } \\
\text { ketable }\end{array}$ & Total & \\
\hline \multicolumn{8}{|l|}{1997} \\
\hline CM 3380 & 81298 & 49317 & 130615 & 37209 & 4029 & 41238 & 42.5 \\
\hline SG 804 & 75081 & 27498 & 102579 & 34405 & 2866 & 37271 & 114.3 \\
\hline CM 3311 & 74005 & 23792 & 97797 & 42101 & 2926 & 45027 & 51.0 \\
\hline SM 494 & 73288 & 62886 & 136174 & 25298 & 5183 & 30481 & 53.0 \\
\hline CM 523 & 62767 & 37660 & 100427 & 26464 & 3219 & 29683 & 39.5 \\
\hline CM 3064 & 55743 & 70837 & 126580 & 19488 & 5129 & 24617 & 31.0 \\
\hline Serrallés & 54697 & 26003 & 80700 & 19586 & 2639 & 22225 & 36.5 \\
\hline CM 4484 & 53800 & 42741 & 96541 & 20029 & 4979 & 25008 & 39.0 \\
\hline Average & 66335 & 42592 & 108927 & 28072 & 3871 & 31943 & 50.8 \\
\hline LSD $(0.05)$ & 22788 & 21028 & 24255 & 9710 & 1802 & 9341 & 27.4 \\
\hline \multicolumn{8}{|l|}{1998} \\
\hline CM 3380 & 75918 & 37361 & 113279 & 28634 & 3640 & 32274 & 61.0 \\
\hline SG 804 & 33476 & 48121 & 81597 & 12057 & 4435 & 16492 & 127.7 \\
\hline CM 3311 & 62468 & 34671 & 97139 & 28792 & 3799 & 32591 & 53.0 \\
\hline SM 494 & 52007 & 53202 & 105209 & 17778 & 3972 & 21750 & 58.1 \\
\hline CM 523 & 42143 & 55294 & 97437 & 13842 & 4367 & 18209 & 63.1 \\
\hline CM 3064 & 29889 & 88471 & 118360 & 6800 & 6420 & 13220 & 35.0 \\
\hline Serrallés & 24808 & 45132 & 69940 & 8246 & 3948 & 12194 & 19.5 \\
\hline CM 4484 & 46029 & 32579 & 78608 & 16379 & 2827 & 19206 & 26.0 \\
\hline Average & 45842 & 49354 & 95196 & 16566 & 4176 & 20742 & 55.4 \\
\hline LSD (0.05) & 23078 & 22778 & 8626 & 8216 & 1933 & 8626 & 35.3 \\
\hline
\end{tabular}

1998 (e.g., clones SG 804 and SM 494), clone CM 3311 showed a reduction of less than one percent. Cassava is drought tolerant (El Sharkawy and Cock, 1984; Ekanayake et al., 1996) but extremely susceptible to excess water (Connor et al., 1981). In view of the wet conditions encountered in 1998 and the small decline in total root production by clone CM 3311, it is recommended that this clone be studied for waterlogging tolerance.

Clones CM 3311, CM 3380 and SG 804 produced the highest marketable root weight in 1997 averaging $37,905 \mathrm{~kg} / \mathrm{ha}$. In 1998, clones CM 3311 and CM 3380 were the best yielders averaging $28,713 \mathrm{~kg} / \mathrm{ha}$ of marketable roots. The latter two clones outyielded local cultivar Serrallés by an average of $20,069 \mathrm{~kg} / \mathrm{ha}$ of marketable roots in 1997 and $20,467 \mathrm{~kg} / \mathrm{ha}$ in 1998 (Table 2). In 1997, clones SM 494, CM 3064, CM 
4484 and CM 3380 produced significantly higher non-marketable root weight whereas clone CM 3064 did so in 1998 (Table 2).

Average total root weight was $35 \%$ lower in 1998 than in 1997. The decline in total root weight could have been caused by less production of roots (Table 2), a reduction in leaf area brought about by leaf abscission during the hurricane, and root rotting as a result of excess soil water. The latter prompted the authors to harvest plants two months earlier than in the 1997 experiment. Clones CM 3064 and SG 804, and cultivar Serrallés had the highest decline in total root weight.

In both years clone SG 804 had a significantly higher concentration of HCN, which averaged $121 \mathrm{mg} / \mathrm{kg}$. There was no significant difference in HCN concentration among the rest of the clones in 1997 and little in 1998 (Table 2). In India, the HCN concentration of local cultivars ranges from 35 to $50 \mathrm{mg} / \mathrm{kg}$ (Manrique, 1996). In Puerto Rico, the mean HCN concentration of high yielding cultivars has been reported to range from 0 to $50 \mathrm{mg} / \mathrm{kg}$ (Ramírez et al., 1983; Badillo-Feliciano, 1984).

The yield data obtained in this study suggest that clones CM 3311 and CM 3380 may have the best potential for cassava production in Puerto Rico. Marketable root yields from clones used in this study were between $15 \%$ and $104 \%$ higher than those obtained from the highest-yielding clones used in previous studies in Puerto Rico (Table 2 and Badillo-Feliciano and Lugo-López, 1975; Ramírez et al., 1983; Badillo-Feliciano, 1984). A panel conducted an informal sensory evaluation of cooked samples of the eight cassava clones used in this study. Clones SM 494 and CM 3380 received the highest ratings in terms of tuber appearance after cooking, texture, flavor, and fiber content (data not shown). It is recommended that a formal evaluation be conducted by a food technologist to assess the potential acceptability of these newly introduced clones.

\section{LITERATURE CITED}

Badillo-Feliciano, J. and M. A. Lugo-López, 1975. Effect of planting system and partial removal of the epidermis of cassava cuttings on growth, yields and root development. J. Agric. Univ. P.R. 60:606-611.

Badillo-Feliciano, J., 1984. Performance of cassava cultivars in an Oxisol in northwestern Puerto Rico. J. Agric. Univ. P.R. 18:375-381.

Centro Internacional de Agricultura Tropical (CIAT), 1985. Yuca: Investigación, Producción y Utilización. Programa Yuca. Carlos Domínguez (ed.). Cali, Colombia, 660 pp.

Connor, D. J., J. H. Cock and G. E. Parra, 1981. Response of cassava to water shortage. I. Growth and yield. Field Crops Research 4:181-200.

Departamento de Agricultura, 2000. Ingreso bruto de yuca. Compendio Estadístico 2000. Oficina de Estadísticas Agrícolas. Departamento de Agricultura, Estado Libre Asociado de Puerto Rico, p. 26.

Ekanayake, I. J., A. G. O. Dixon and M. C. M. Porto, 1996. Performance of various cassava clones in the dry savanna region of Nigeria. In: Kurup, G. T., M. S. 
Palaniswami, V. P. Potty, G. Padmaja, S. Kabeerathumma and S.V. Pillai (eds.). Tropical Tuber Crops: Problems, Prospects and future Strategies, pp. 207-215. Science Publishers, Inc., Lebanon, NH.

El Sharkawy, M. A and J. H. Cock, 1984. Water use efficiency of cassava. I. Effect of air humidity and water stress on stomatal conductance and gas exchange. Crop Sci. 24:503-507.

Food and Agriculture Organization. FAOSTAT statistics database: Agriculture. Available at http:/apps.fao.org/cgi-bin/nph-db.pl?subset=agriculture2000 (accessed June 2001).

Howeler, R. H., 1996. Diagnosis of nutritional disorders and soil fertility management of cassava. In: Kurup, G. T., M. S. Palaniswami, V. P. Potty, G. Padmaja, S. Kabbeerathumma and S. V. Pillai (eds.). Tropical Tuber Crops: Problems, Prospectus and Future Strategies, pp. 181-193. Science Publishers, Inc., Lebanon, NH.

Manrique, L. A., 1996. Tropical root crops: potato, cassava, sweet potato, taro. Manrique International Agrotech, Honolulu, Hawaii. pp. 139-232.

Puerto Rico Planning Board, 2000. External Trade Statistics. In: Caballero-Mercado, J. R., L. H. Olmeda and A. L. Cruz (eds.). Government of Puerto Rico, Office of the Governor. October 2000. pp. 615.

Ramírez, O. D., J. J. Green and I. Beauchamp de Caloni, 1983. Evaluation and acceptability of cassava cultivars. J. Agric. Univ. P.R. 17:16-21.

SAS Institute, 1990. User's guide. Statistics, Version 6. SAS Institute, Cary, NC.

University of Puerto Rico Agricultural Experiment Station, 1997. Technological package for the production of root and tuber crops. Publication 101. College of Agricultural Sciences, University of Puerto Rico, pp. 34. (In Spanish.) 